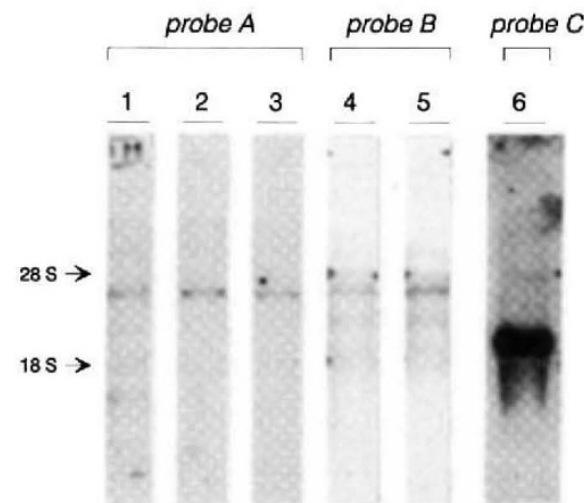

FIG. 2 Northern blots of brain RNA from hamster (lanes 1, 6), wild-type mice (lanes $2,4)$ and mice homozygous for ablated PrP genes $\left(P r n-p^{\circ / O}\right.$; lanes 3,5$)$. The $4.5-k b$ RNA species is detected in brain tissues of both wild-type and Prn-p ${ }^{O / O}$ mice. Sense probes A (lanes 1-3) and B (lanes 4 and 5) were used to detect the 4.5-kb RNA, antisense probe C (lane 6) detected PrP mRNA. Northern analyses were done as described in Fig. 1, with total hamster or mouse RNA ( $3 \mu \mathrm{g}$ per lane) and polyadenylated mouse RNA $(0.6 \mu \mathrm{g}$, lane 4, $1.2 \mu \mathrm{g}$, lane 5). Exposure times: lanes $1-3,6,15 \mathrm{~min}$; lanes 4, 5, $9 \mathrm{~min}$.

tion is not greatly altered after scrapie infection, and demonstrate that the RNA is not derived from the PrP gene. If the 4.5-kb mRNA, despite its being derived from a locus other than the PrP gene, encoded an 'anti-prion protein', this might have intriguing implications. It has recently been described for four independent proteins that peptides encoded by antisense sequences correspond structurally to binding proteins or receptors $^{7-10}$. Thus, a putative 'antiprion protein' may be pertinent to the normal function of the prion protein.

\section{Markus Moser}

\section{Bruno Oesch}

Institut für Hirnforschung,

Universität Zürich, 8029 Zürich,

Switzerland

Hansruedi Büeler

Institut für Molekularbiologie I,

Universität Zürich,

8093 Zürich, Switzerland

1. Prusiner, S. B. Science 252, 1515-1522 (1991).

2. Oesch, B. et al. Cell 40, 735-746 (1985)

3. Basier, K. et al. Cell 46, 417-428 (1986)

4. Goldgaber, D. Nature 351, 106 (1991).

5. Hewinson, R. G., Lowings, J. P., Dawson, M. D. \& Woodward, M. J. Nature 352, 291 (1991).

6. Bueler, H. et al Nature 356, 577-582 (1992)

7. Ghiso, J., Saball, E., Leoni, J., Rostagno, A. \& Frangione, B. Proc. natn. Acad. Sci. U.S.A. 87, 1288 1291 (1990)

8. Brentani, R. R. et al. Proc. natn. Acad. Sci. U.S.A. 85 364-367 (1988)

9. Elton, T. S., Dion, L. D., Bost, K. L., Oparil, S. \& Blalock, J. E. Proc. natn. Acad. Sci. U. S. A. 85. 2518-2522 (1988)

10. Bost, K. L., Smith, E. M. \& Blalock, J. E. Proc. natn. Acad. Sci. U.S.A. 82, 1372-1375 (1985) 11. Westaway, D. et al. Cell 51, 651-662 (1987).

\title{
Cannibals among the Neanderthals?
}

SIR - The question of prehistoric cannibalistic behaviour is a hotly debated issue $^{1-3}$. Recently, 13 Neanderthal remains were discovered by one of us (A. D.) at a depth of more than 6 metres in a small excavation in the Abri Moula, near Valence, southeast France. The biostratigraphic context belongs to a temperate period. We discovered human bones among lithic artefacts, defined as typical Mousterian, and faunal remains. There were four bones in level C, eight in level $\mathrm{D}$ and one in level E. Radiocarbon dates for charcoal from level $\mathrm{C}$ gave an age in excess of $49 \mathrm{kyr}$. The

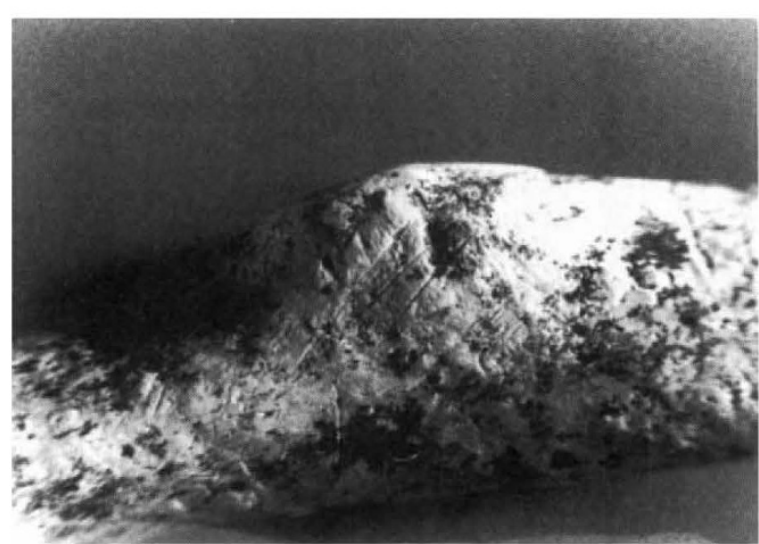

Radius showing clear cutmarks on the bicipital tuberosity $(\times 0.9)$. initial palaeoanthropological identification showed seven fragments of cranial vault, three teeth and three postcranial fragments. Although none of the osteological fragments was redundant, the disparities in the robustness of several pieces suggest that more than one individual is represented, a conclusion consistent with the fact that the remains come from two distinct levels.

We could not determine how old the individuals were at the time of death, but a relatively young age is suggested by the slenderness of several fragments. The presence of several Neanderthal autapomorphies is fully consistent with the archaeological context. Four of these remains (three skull fragments and a proximal radius epiphysis; see figure) bear clear cutmarks, undoubtedly resulting from a flint tool, associated with signs of fresh bone breakage. Cutmarks on postcranial Mousterian human remains have, until now, been observed only at the sites of Krapina ${ }^{4}$ and of Combe-Grenal ${ }^{5}$.

Some researchers define the existence of prehistoric cannibalism by the surface markings on cranial and post-cranial bones, the degree of fragmentation, and by the presence of bones among kitchen refuse. Others have disputed the reliability of the original excavation work and evidence-gathering techniques, attributing the breakage to sediment pressure or rockfall and some of the presumed cutmarks to damage during bone recovery ${ }^{6}$. Cutmarks that could not be disputed were attributed, on this view, to noncannibalistic ritual practice.

At the root of the controversy lie the different interpretations given to certain types of bone fractures. Evidence from ethnographic studies of mortuary practices involving bone defleshing and secondary burial shows that the bones are gathered with great care and never broken up ${ }^{7,8}$. Consequently, it is very difficult to attribute fresh bone breakage accompanied by cutmarks to a simple mortuary ritual. Some of the objections raised in connection with the Krapina bones are not valid for the Abri Moula material because the bone fragments were found apart in undisturbed levels containing few rocks. The great interest of this new discovery is highlighted by the presence of a fresh bone breakage pattern (V-shaped and bevelled break pattern at an oblique angle) associated with cutmarks. The same modifications can be observed on faunal remains mixed with human bones.

Although our new osteological data cannot prove the practice of cannibalism among the Neanderthals, they constitute an important argument in favour of the hypothesis that such practices could have occurred among the Middle Palaeolithic inhabitants of Western Europe.

Alban Defleur

Olivier Dutour

LAPMO, Université de Provence, URA 164 du CNRS,

29 Avenue Robert Schuman,

F-13621 Aix en Provence,

France

Hélène Valladas

CFR, CEA-CNRS,

Avenue de la Terrasse,

F-91198 Gif-sur-Yvette,

France

\section{Bernard Vandermeersch}

Laboratoire d'Anthropologie,

Université de Bordeaux,

F-33405 Talence,

France

1. Villa, P. et al. Science 233, 431-437 (1986)

2. Bahn, P. G. Nature 348, 395 (1990)

3. White, T. D. \& Toth, N. Curr. Anthrop. 32, 118-124 (1991).

4. Trinkhaus, E. J. hum. Evol. 14, 203-216 (1985)

5. Le Mort, F. Bull. Soc. Préhist. Fr. 86/3, 79-87 (1989).

6. Russell, M. D. Am. J. phys. Anthrop. 72, 373-397 (1987).

7. Ubelaker, D. H. Smithsonian Contr. Anthrop. 18 (Washington, DC, 1974).

8. Ferembach, D. \& Lechevallier, M. Paléorient 1, 223230 (1973). 